\title{
CHALLENGES FOR THE THEORY AND PRACTICE OF BUSINESS COACHING
}

Dr Anna Blackman*

Senior Lecturer

College of Business, Law \& Governance

James Cook University

Townsville

anna.blackman@jcu.edu.au

P: +61747814100

F: +61747814019

Dr Blackman is a Senior Lecturer at James Cook University, her research interests are in the areas of Human Resource Management, Coaching, Small Business Management, Well-Being, Rural Business Development.

Professor Gianna Moscardo

College of Business, Law \& Governance

James Cook University

Townsville

gianna.moscardo@jcu.edu.au

P: +61747814254

Professor Gianna Moscardo has qualifications in applied psychology and sociology. Her qualifications in applied psychology and sociology support her research interests in understanding how communities and organisations perceive, plan for, and manage tourism development opportunities and how tourists learn about and from their travel experiences.

Professor David Gray

Professor of Leadership and Organisational Behaviour

University of Greenwich

Old Royal Naval College Park Row London SE10 9LS

\section{D.E.Gray@greenwich.ac.uk}

David Gray is Professor of Leadership and Organisational Behaviour at the University of Greenwich having been previously Professor of Management Learning at the University of Surrey, UK. He also worked at the London Stock Exchange where he was director of a national training development initiative for the UK securities industry. His research interests, and publication record, include innovation in SMEs, research methods (with a focus on research design and quantitative and qualitative methods), management learning (particularly coaching and mentoring), reflective learning, and e-learning. 
Please cite as: A. Blackman, G. Morsardo and D.E. Gray (2016) 'Challenges for the Theory and Practice of Business Coaching: A Systematic Review of empirical evidence'. Human Resource Development Review, 15(4): 459-486.

\title{
CHALLENGES FOR THE THEORY AND PRACTICE OF BUSINESS COACHING: A SYSTEMATIC REVIEW OF EMPIRICAL EVIDENCE
}

\begin{abstract}
Until recently there has been little published systematic empirical research into business coaching. This paper reports on a systematic, critical review of 111 published empirical papers investigating business coaching theory, processes and outcomes. The present paper identifies a significantly larger body of empirical research than covered in previous reviews and uses a Systematic Review method (SRm) to conduct a comprehensive review of the available empirical evidence into business coaching effectiveness focusing on implications for theoretical development, practice (within human resource development) and further research in this area. This review identifies convergence around factors that contribute to perceived effective coaching practice but nevertheless highlights a number of issues to be resolved in further research. These include determining the primary beneficiaries of coaching, the factors that contribute to coach credibility, and how the organisational and social context impacts on coaching. Weaknesses in coaching research methodology and research gaps are also noted.
\end{abstract}

Key words: coaching, business coaching, coaching effectiveness, coaching research, systematic review 


\section{INTRODUCTION}

Many business organisations make substantial investments in human resource development (HRD) programs hoping that these will increase productivity and be a source of competitive advantage for their organisation (Fulmer, Gibbs, \& Goldsmith, 2000). Business coaching is one type of HRD activity that has become very popular in recent years. In 2003 Capuzzi Simon claimed that there were tens of thousands of business coaches in the USA and three years later Fillery-Travis and Lane (2006) described business coaching as a \$2 billion per annum market. Liljenstrand and Nebeker described business coaching as "the fastest growing field within consulting" (Liljenstrand \& Nebeker, 2008:58).

In the present paper business coaching is defined as a formal relationship with a designated coach, "in which the coachee and coach collaborate to assess and understand the coachee and his or her leadership developmental tasks, to challenge current constraints while exploring new possibilities, and to ensure accountability and support for reaching goals and sustaining development" (Ting \& Hart, 2004, p. 116). While much of the organizational coaching literature uses the term 'executive coaching', we use 'business coaching' as a more inclusive description, incorporating all forms of coaching (including executive, management, team and leadership coaching) taking place in business. Business coaching can be conducted by either external coaches or internal line managers or human resource management (HRM) and HRD staff (Brandl, Madsen, \& Madsen, 2009; Teague \& Roche, 2011). While internal coaching is recognised within HRM/HRD as a critical skill for all managers to have as part of their repertoire of HR tools (Swart \& Kinnie, 2010), it is usually informal and often difficult to distinguish from mentoring (Doorewaard \& Meihuizen, 2000). Discussions of business coaching thus usually distinguish it from mentoring by focussing on external coaches and by highlighting the formal, structured nature of the relationship between the coach and coachee (Witherspoon \& White, 1996). Even here though there are overlaps, Garvey, Stokes \& Megginson, (2009) pointing out that many mentoring programmes, at least in the USA, are 
formally structured. Where coaching and mentoring differ, is that coaching is more shortterm and focused on specific developmental issues, while mentoring takes a broader view of the person (Hawkins \& Smith, 2013). Others stress that mentoring is often a voluntary activity within an organization, providing psychosocial support, while coaching is more often a paid, professional activity, with the coach acting as a facilitator of learning and development within an organizational context (Gray, Garvey, \& Lane, 2016). While acknowledging that coaches often have to work with psychological issues (Bachirova, Cox, \& Clutterbuck, 2014), we see business coaching as working, largely, with functioning people, while therapy focuses on those with some form of dysfunction or disorder (AM Grant, 2001).

There are several different approaches to coaching and any one coaching program can include a range of techniques and activities. Coaching programs can also vary in terms of the number, variety and types of techniques that are used within the program, the length of the program, and the type of consultant employed as the coach (Blackman, 2006). The only restriction used in the present paper is that the coaching is aimed at business or professional development (within a business) and that it is conducted with a coach from outside the immediate work unit and/or as part of a structured program.

While there have been many articles written about what coaching is, advocating for its adoption and describing how to coach, little critical, systematic, empirical research has been published about the effectiveness of business coaching for either the individual or the organisations they work for (Joo, 2005; Leedham, 2005). Few coaching programs have been formally evaluated within organisations (McDermott, Levenson, \& Newton, 2007) and, until recently, little academic research has examined business coaching (Kilburg, 2001; Passmore \& Gibbes, 2007). Business coaching has however, become a topic of academic interest and there has been a growing number of empirical studies published since 2005 (Ely et al., 2010; Jarvis, Lane, \& Fillery-Travis, 2006). This emerging empirical literature offers an opportunity 
to begin to assess the many claims made for and about business coaching. This study reports on a systematic review of the published empirical research analysing the processes and outcomes of business coaching. In doing so, it makes an important contribution to the current limited literature on the effectiveness of coaching in general and business coaching in particular. Furthermore, it offers a theoretical framework to guide both future research and practice by identifying the pre-conditions for coaching, the theoretical approaches taken to business coaching research, the processes and context of coaching, how coaching outcomes are measured and the credibility of business coaching outcomes.

\section{THE PRACTICAL AND THEORETICAL DEVELOPMENT OF BUSINESS COACHING}

According to Natale and Diamante (2005), there have always been coaches operating in business but the role and its associated activities were not formally recognised. This formal recognition of business coaching as a distinct staff development field of its own came about in the 1980s (Hudson, 1999; Kampa-Kokesch \& Anderson, 2001; Kilburg, 1996a, 1996b; Olesen, 1996; Tobias, 1996). Harris (1999) describes three periods in the history of business coaching. Firstly, the period between the years 1950 and 1979, when a "few professionals used a blend of organizational development and psychological techniques in working with executives" (Kampa-Kokesch \& Anderson, 2001, p. 207). Secondly, a middle period between 1980-1994 characterised by increasing and standardizing of professional services (KampaKokesch \& Anderson, 2001). The third period runs from 1995 to the present. In this period there has been an increase in publications and the establishment of professional organisations for business coaching (Kampa-Kokesch \& Anderson, 2001). As the practice of business coaching is considerably more advanced than the depth of research, there have been calls to direct more effort towards critically analysing both the concepts and practices of business coaching (Diedrich \& Kilburg, 2001) and the development of more theory based research (Stone, 2007). While there is no universal agreement regarding the definitions of HRD and HRM, it is generally accepted that HRM more often emphasizes policy, staffing, HR- 
related IT, compensation, and other policy related issues. HRD is most often described to be development, learning, and performance focused at individual, group, organization and larger system levels. Therefore, coaching can be classed as a key HRD related activity (Beattie et al., 2014). Bachkirova, Cox and Clutterbuck (2014) describe coaching as " $a$ human development process that involves structured, focused interaction and the use of appropriate strategies, tools and techniques to promote desirable and sustainable change for the benefit of the coachee and potentially for other stakeholders" (p. 1).

Accordingly, there is an emerging field of empirical research that is addressing these problems with a growing number of published papers reporting research data (Jarvis, 2004; Jarvis et al., 2006) and this has generated several academic reviews. Webster and Watson (2002) highlight the importance of critical literature reviews for theoretical development in the various fields in management. They note that literature reviews provide two key functions, the directing of new research through the identification of topics that have been examined in detail and of gaps in knowledge; and the description of cumulative patterns of results that can support theoretical development. The early reviews into business coaching, those conducted up to and including 2005, consistently reported a limited number of empirical papers. Kampa-Kokesch and Anderson (2001) found only seven empirical research based papers, Feldman and Lankau (2005) were able to analyze 20 empirical studies, and Joo (2005) identified 11 research articles out of 78 academic papers on business coaching. Lowman (2005) and Bennett (2006) also provided early reviews but in each case they focused only on papers in special issues of journals or as presented at meetings dedicated to business coaching.

All these early reviews focused on what Passmore and Fillery-Travis (2011) have described as the first stage of the development of a new academic area - establishing definitions and exploring the scope of the phenomenon. Their second stage involves more consideration of 
how to evaluate or measure the concepts under study, development of research methods and initial development of theory. Four more recent reviews are clearly within this second stage, although each with a particular focus. Passmore and Gibbes (2007), for example, reviewed 23 empirical papers but concentrated their review on assessing the potential contribution of counselling research and theory to business coaching. Ely and colleagues (2010) reported on a larger number of studies (49) but selected only those studies that addressed or measured leadership development as an outcome from the coaching programs. In a similar fashion De Meuse, Dai and Lee (2009) reviewed empirical studies into coaching, seeking to assess return on investment (ROI) and so only examined six quantitative studies. In a similar fashion three meta-analytic reviews have been conducted in recent years. Theeboom, Beersma and van Vianen (2014) identified 18 quantitative empirical studies presented in sufficient detail to conduct a meta-analysis, while Sonesh and colleagues (2015) identified 24 studies suitable for meta-analysis, and Jones, Woods and Guillaume (2015) analysed 17 studies. In all cases the results of the meta-analyses provide some limited evidence that coaching was associated with positive effects on outcomes. These limitations included a heavy reliance on self-reported outcomes and a lack of control groups suggesting that it is was not possible to clearly link coaching to outcomes (Theeboom et al., 2014), stronger effects for coachee perceptions of the quality of the coach-coachee relationship than for other sorts of goals or outcomes and stronger effects for student samples than for executive and other non-academic samples (Sonesh et al., 2015) and lower effect sizes for multi-source feedback measures (R. Jones et al., 2015). Taken as a whole these reviews suggest that under certain very specific conditions some positive relationships can be detected between coaching and individual benefits. The use of meta-analysis does, however, limit the number of studies that can be considered and so do not provide a very comprehensive overview of the available evidence. 
In recent years several wider reviews of business coaching have been published. Passmore and Fillery-Travis (2011) provided a comprehensive review of business coaching research up to the late 2010s, but details on how they selected papers for inclusion in their review are limited and the review incorporated both research papers and other discussions of business coaching, with a continuing emphasis on connections to the counselling literature. Stern and Stout-Rostron (2013) provided a more traditional narrative literature review based on 263 papers about coaching from both a wide range of disciplines. The aim of this review was to describe coverage of 16 major topics in business coaching and the review did not address issues of research quality or the nature of evidence about the topics examined. Bartlett, Boylan and Hale (2014) examined definitions and descriptions of coaching by analyzing the key words of 533 papers. Again the review did not distinguish between descriptive, advocacy and empirical research based papers and did not address the nature of evidence about coaching.

A 2014 special issue of the journal Advances in Developing Human Resources offered a number of papers that reviewed and explored aspects of business coaching. Three were focused on specific topics including coaching measurement scales action learning ( $\mathrm{O}^{\prime} \mathrm{Neil} \&$ Marsick, 2014), and how coaching is integrated into HRD processes (Beattie et al., 2014). The first described the major theoretical traditions in coaching mapping these to current coaching practices (Cox, Bachkirova, \& Clutterbuck, 2014). The second presented a framework on coaching definitions and competencies to inform the development of accreditation processes and coach credentials (Maltbia, Marsick, \& Ghosh, 2014). While each of these papers offers a synthesis of ideas based on reviews of previous research, and included both empirical studies and other documents, neither aimed to provide a comprehensive overview of the field. The Cox et al. (2014) paper, for example, provides an overview of the main theoretical approaches that can be linked to coaching practice but not 
a systematic assessment of how these theoretical approaches have been linked to evidence of the effectiveness of these coaching practices.

Briner and Denyer (2012) distinguish between several different types of academic literature reviews. The first type is a traditional narrative review which seeks to provide a comprehensive overview, often presented in chronological order of what has been studied in a field and what major conclusions can be drawn from this research. The reviews by Kampa-Kokesch and Anderson (2001), Feldman and Lankau (2005), Joo (2005), and Passmore and Fillery-Travis (2011) are examples of this type of review. A second type of review is the meta-analytic review (eg., De Meuse et al., 2009; Jones et al., 2015; Sonesh, etal., 2015; Theeboom et al., 2013) which are necessarily constrained to particular types of studies and the nature of the data reported by those studies. A third type of review is one based on themes which presents the results of a set of papers relevant to a specific theme or question (Briner \& Denyer, 2012). In the previous section several such reviews were noted. Finally there are what Briner and Denyer (2012) refer to as selective, expert reviews which provide an argument about issues or concepts supported by a selection of references (eg., Cox et al., 2014; Maltbia et al., 2014). While this latter type of review can offer synthesis and direction to a field they are not focussed on systematically and critically evaluating the available evidence in a field and it has been suggested that these expert reviews could be supported and extended by the final category of systematic reviews (Briner \& Denyer, 2012) - as in our study.

Briner and Denyer (2012, p. 329) define a systematic review as one that "addresses a specific question, utilizes explicit and transparent methods to perform a thorough literature search and critical appraisal of individual studies, and draws conclusions about what we currently know and do not know about a given question or topic". This type of systematic review is common in fields such as medicine, law and psychology but is only recently being adopted in 
business and management (Rojon, McDowall, \& Saunders, 2011) despite calls for, and explanations of, SRm in management beginning more than a decade ago (Tranfield, Denyer, \& Smart, 2003). SRm can be contrasted with other more traditional approaches to literature reviews including meta-analytic approaches that re-analyse data from quantitative studies, argument/thematic reviews which argue for a particular standpoint supported by selective references to research, and expert/narrative reviews that focus on an individual synthesis of an area (Briner \& Denyer, 2012). While each of these approaches has its benefits, they also have limitations. Meta-analytic reviews, for example, are limited to very specific types of quantitative studies reported in sufficient detail to facilitate analyse and so often cannot consider the full range of evidence available on a topic (Rousseau, Manning, \& Denyer, 2008). Thematic and expert reviews are often limited by a failure to explicitly describe how papers were selected for review and how they were analysed, making them open to potential bias on the part of the review authors (Rojon et al., 2011). According to Jones, Coviello and Tang (2011) this approach is especially useful in newer areas where practice and advocacy may not be well connected to emerging research, as is the case for the effectiveness of business coaching.

The present paper sought a unique approach to critically examining the issue of coaching effectiveness using a Systematic Review methodology which has not been used previously in the business coaching literature. A systematic review is critical because it evaluates the quality of the evidence provided in the empirical literature rather than just describing the conclusion of the papers reviewed. In the area of business coaching such an approach supports a more comprehensive but focused review incorporating a larger body of empirical evidence than has previously been examined in narrative or meta-analytic reviews. As a systematic review it includes all the available empirical papers and an assessment of the quality of the evidence in these papers it offers a way to test the claims made in the thematic and expert reviews. In this latter context it can be seen as a form of triangulation. 
Given the dramatic increase in academic empirical studies evident in recent years, the present review provides an assessment of the effectiveness of coaching based on a larger body of empirical evidence than was previously available, a comprehensive overview of the field that is not limited by a specific focus on one aspect of coaching, and offers direction for a more evidence based conceptual framework to guide future research and practice. A core contribution of the present review is that it is based on a specific type of review methodology that has not been previously used in the field.

\section{SYSTEMATIC REVIEW METHODOLOGY (SRm): AN OVERVIEW}

The use of SRm is aimed at avoiding these biases by having reviewers follow and clearly report a systematic process for the search, selection, inclusion and analysis of a comprehensive set of studies in an area (Briner \& Denyer, 2012). The four core principles of $\mathrm{SRm}$ are that the process is systematic and organized to avoid researcher bias, there is a transparent and explicit audit trail for decisions, the review is replicable and easily updateable, and it synthesizes the evidence to answer specific pre-set questions (Briner \& Denyer, 2012; Denyer \& Tranfield, 2009; Rousseau et al., 2008; Tranfield et al., 2003) . While there are no standardized procedures set down for SRm examples all share four major steps:- identifying a clear review question focussed on assessing the available evidence on a key topic; there is a clear protocol used to locate and select relevant studies and the steps in this protocol are designed to minimize reviewer bias; there is a critical appraisal of the studies included; and this analysis is synthesized to reveal new knowledge in an area (Briner \& Denyer, 2012; Denyer \& Tranfield, 2009; Rousseau et al., 2008; Tranfield et al., 2003).

Thorpe, Holt, Macpherson and Pittaway(2005)summarised the steps suggested for a systematic review by Rousseau et al (2008) and Tranfield et al (2003) into three main steps 
with several actions within each step and the present paper followed this procedure. The first main step is to define the objectives of the review and establish the guiding questions. Building on the previous reviews of coaching and addressing the gaps in their approaches, this systematic review of empirical research into the effectiveness of business coaching was guided by the following research questions:

1. Is business coaching an effective development tool and in what areas is it effective?

2. Is business coaching more effective than other development or training techniques?

3. What factors contribute to effective business coaching outcomes?

4. What evidence is available to inform key debates in the area on the factors that contribute to coach credibility?

5. What gaps exist in research into business coaching?

The second main step is to conduct the research review and this consists of searching for relevant research, using criteria to decide on which studies to include in the review, coding the included studies, and analysing these studies (Thorpe et al., 2005). The search procedure for the present review built upon the work of Grant (2005b) who conducted a review of peer-reviewed behavioural science journals and identified 175 articles that included some discussion of business coaching but only 24 of these were reports of empirical research. For the present paper these 24 articles were taken and supplemented a search for articles published in peer-reviewed journal since March 2005. The decision to focus on peerreviewed journals was consistent with reviews by Jones et al(2011), and Keupp, Palmie and Gassmann (2012). Searches of the electronic academic databases Google Scholar, Proquest (which included Informit, Psychinfo and PsychArticles), Expanded Academic ASAP (which included Infotrac), Emeraldinsight, IngentaConnect, Sage Premier Journals, ScienceDirect, SpringerLink, Taylor and Francis Online and Wiley Online, were conducted using the terms "business coaching" and "executive coaching". References within key articles and the 
existing review papers and Grant's (2011) annotated bibliography were also used to identify any additional papers. Following the guidelines of Parris and Peachey (2013) results of the searches were judged against three inclusion criteria:- the papers were in English, they addressed the effectiveness of business or executive coaching and they reported on empirical research. For this paper, empirical research is defined as "the process of developing systematized knowledge gained from observations that are formulated to support insights and generalizations about the phenomena under study" (Lauer \& Asher, 1988, p. 7). Based on this definition and, consistent with both the suggestions of Briner and Denyer (2012) and a critical realist research approach, the review included both quantitative and qualitative research. One researcher applied the selection criteria and ambiguous papers were checked by a second researcher before a joint inclusion decision was made. The application of this protocol resulted in a final set of 111 empirical papers for review. Tables listing the reference details for these studies and summarising their key characteristics are available on request from the corresponding author. Of these 111 papers 15 were published prior to 2000, with the remaining 96 published since 2004, supporting claims made about an upward trajectory in this area by Ely et al (2010). Thirty five articles were published in 2012 to 2015 further demonstrating that the field of coaching research is developing and that considerably more evidence is now available for consideration than previous narrative reviews such as those provided by Passmore and Fillery-Travis (2011).

\section{FINDINGS}

In this section we first report on the methodological and theoretical approaches taken by the business coaching articles reviewed. The findings are then organised by the first four research questions, the fifth research question focused on gaps is answered by considering the findings overall and is discussed in the discussion. 


\section{Methodological Approach}

These 111 research papers were then organised into three groups according to the research designs used to evaluate or study business coaching. This approach follows the suggestions made by Passmore and Fillery-Travis (2011) that there is a link between different methodological styles and the types of questions addressed. Within each category each study was coded according to the nature of the sample, the method used and major findings. It is important to note that there is, however, considerable variability in research quality in each grouping.

The first group consisted of case studies and one group post-test only designs ( 54 papers were reviewed). These types of approaches have been classified as pre-experimental and while they can provide valuable insights into the process of coaching and indications of patterns and trends (Kilburg, 2004), they do not provide independent evidence that a change has occurred and they can be confounded by numerous sources of bias (Shadish, Cook, \& Campbell, 2002). The studies reported in the first group were either case studies describing a one-on-one set of coaching sessions or an analysis of the target coaching exercise using interviews and questionnaires. While a variety of scales and measures were used to evaluate the coaching almost all relied upon coachees' and/or coaches' selfreported subjective evaluations of effectiveness. The limitations of using only subjective participant evaluations to assess the success of coaching have been discussed in detail elsewhere (Ely et al., 2010; Passmore \& Fillery-Travis, 2011; Passmore \& Gibbes, 2007) and include issues such as rating the coach instead of the effectiveness of the coaching process and everything it involves, participants that are going through the coaching process at the time they evaluate it are more likely to rate different aspects more highly compared to those that have time to reflect. Thus, it is not possible from this set of studies to make very strong claims about the effectiveness of coaching in general or its effectiveness compared to other 
training opportunities. These studies do, however, offer insights into the process of coaching and it is possible to explore the links between characteristics of the coachee, coach and coaching process and differences in perceived outcomes (Kilburg, 2004; Lowman, 2005). Further, it could be argued that in each specific study the sample size and nature often limits generalisation of the results. Taken as a whole, however, the set of studies provides consistent results across a wide range of different samples and coaching programs.

The second group consisted of quasi-experimental studies that included either a one group pretest-post-test design or a non-equivalent control group design (34 papers were reviewed). This group of studies offers some potential to begin to assess the overall effectiveness of coaching programs, but again this is limited to participants' evaluations on a small range of outcomes (Shadish et al., 2002). All the studies in this group focussed on coaching techniques only. One particular issue with the studies in both of these groups is that of the Hawthorne or halo effect where improved performance results simply from having someone pay attention to respondents' attitudes and feelings (Dyck \& Neubert, 2010).

To avoid this possibility and to examine claims made about business coaching versus other training or development options (Research Question 2), a third group of studies that combined coaching with other techniques was also identified (23 studies were reviewed). The majority used coaching as part of a more extensive training program and evaluating coaching was not the sole purpose of the research. It had been hoped that this group of studies might provide some insights into the relative effectiveness of coaching versus other training techniques but more detailed analysis found that this was not possible. Typically, these studies evaluated the whole program with only limited information provided on evaluations of individual components. The discussions of results did, however, provide some additional insights into the contributions of different aspects of coaching to perceived 
program success. For example, a study by Thach (2002) of 281 executives, found that the combination of multi-rater feedback and individual coaching do increase leadership effectiveness up to $60 \%$ according to direct report and peer post-survey feedback.

\section{Conceptual/Theoretical Approaches}

The majority of the 111 studies reviewed did not design their research guided by a particular theoretical model or conceptual framework, although the development of the coaching program that was evaluated may have been guided by any number of implicit concepts and theories. Seven concepts or theories emerged from those studies that did explicitly use a theory or concept to guide their research including: psychotherapy (Wasylyshyn, Gronsky, \& Hass, 2006), cognitive behaviour therapy (Cleary \& Zimmerman, 2004), approaches designed to improve self-efficacy (Baron \& Morin, 2010; Evers, Brouwers, \& Tomic, 2006), mindfulness (Spence, Cavanagh, \& Grant, 2008), concepts related to leadership (Konczak, Stelly, \& Trusty, 2000; Levy, Cober, \& Miller, 2002), action learning (Douglas \& McCauley, 1999) and the use of attitude and behaviour change theories from the field of persuasive communication (Blackman, 2008, 2010). Cox et al. (2014) argued that concepts from adult learning offered potential for coaching practice and could be linked to many of the existing theories used in practice. The present review indicated that, with the exception of the Douglas and McCauley (1999) study using action learning, this area has not been given much consideration by academic researchers providing support for Cox et al.'s (2014) recommendations.

This diversity of theoretical approaches reflects the larger field where ideas range from broad philosophies, such as humanistic psychology (Eggers \& Clark, 2000), through to very specific concepts such as leadership, which are connected to multiple theories (Ely et al., 2010), to possible links to other areas of activity such as counselling psychology (Passmore \& 
Gibbes, 2007), which also in turn are connected to multiple theories related to areas of process and outcome, supervision and training, career development and health to name a few. Many specific coaching activities are recommended for their inclusion of cognitive behavioural therapy (AM Grant, 2005b) and psychodynamic approaches (Foster \& Lendl, 1996), but almost none have been systematically analysed or tested in coaching research.

The practice of coaching draws from many of the theoretical constructs and psychological models and practices of mentoring, training and counselling with the latter the most common given the background of many coaching consultants. Within the field of counselling there exist many different theoretical approaches including psychoanalysis, Adlerian therapy, Gestalt therapy, cognitive behaviour therapy, and rational emotive therapy (Corey, 2012). While these are not simple alternatives to each other, they share a common focus on the individual being counselled or coached and challenging how they think about themselves and their situation and while not seeing these individuals as sick, there is a tendency in the counselling literature to assume that the individual being counselled or coached has a problem (Corey, 2012). Other authors in the coaching literature on coaching tend to see the organisation as having the problem and thus look more towards instruction and learning theories as a source of theoretical framework (Fournies, 1999; Wrench, McCroskey, Berletch, Powley, \& Wehr, 2008). In this approach, theories from the area of persuasive communication are beginning to emerge as options for coaching practice and research (Peltier, 2001; Wrench et al., 2008). The two theoretical traditions are not necessarily in conflict and merging the two is likely to produce the best overall outcome.

\section{Research Question 1: Benefits or Outcomes of Coaching}

The following is a summary of the benefits often claimed for coaching offered as an extensive list that includes outcomes relevant to the coachee and to the employing 
organisation. For the coachee benefits are said to include: improving/establishing a work/life balance (Gegner, 1997), improving psychological and social competencies, improving/advancing career development (Wales, 2003), improving self-awareness and assertiveness (Bozer, Sarros, \& Santora, 2014; Gatling, Castelli, \& Matthew, 2013; Wales, 2003), increasing confidence (Wales, 2003), developing relationships/networks/interpersonal skills (Wales, 2003), adapting to change more effectively, helping to set and achieve goals (Smither, London, Flautt, Vargas, \& Kucine, 2003), role clarity (Kim, Egan, Kim, \& Kim, 2013; Sonesh et al., 2015) and changing behaviours (AM Grant, 2005a; Wasylyshyn, 2003). For employers benefits for the organisation include; increased productivity (Olivero, Denise Bane, \& Kopelman, 1997), acting as a support mechanism for other training programs (Wales, 2003), and improvements to communication (Graham, Wedman, \& Garvin-Kester, 1993) and effectiveness of organisations or teams (Hagen \& Garvrilova Aguilar, 2012). There are also suggested outcomes that benefit both the coachee and the employer and these include; improvements in interpersonal dynamics/teamwork (Hagen \& Garvrilova Aguilar, 2012), higher levels of motivation (Sonesh et al., 2015), increased job satisfaction/job retention/company loyalty (Ellinger, Ellinger, \& Keller, 2003; Olivero et al., 1997), increased skill levels(Wales, 2003), able to deal with stressful situations more effectively and improved leadership and management.

All of the reviewed studies reported that the target coaching program was seen by most participants as effective in some way (Parker-Wilkins, 2006). Overall there was support for a range of benefits and outcomes with the exception of direct evidence of career advancement, although this was often assumed to be likely to happen in the future. Additional benefits in terms of coachee skills and behaviours were also proposed including:-

- Improved ability to delegate appropriately (McGovern et al., 2001); 
- Better stress management (Ladergard, 2011; Wales, 2003);

- Enhanced ability to address workplace conflict and work autonomously (Blackman, 2008; Gray, Ekinci, \& Goregaokar, 2011; Smith Glasgow, Weinstock, Lachman, Dunphy Suplee, \& Dreher, 2009);

- Increased personal accountability (Kralj, 2001);

- More innovation and creativity (Norlander, Bergman, \& Archer, 2002; Styhre, 2008);

- Higher levels of initiative (Blackman, 2010; Sonesh et al., 2015); and

- More flexibility and adaptability (Hall, Otazo, \& Hollenback, 1999).

It is important to remember, however, that these conclusions were based almost entirely on participant evaluations conducted during and/or immediately after the coaching experience.

It can be argued that perceived or subjective effectiveness is likely to be an important prerequisite for actual changes in coachee attitudes and behaviour, but there is little evidence that describes the nature or extent of this link. Certainly research into training effectiveness more generally in HRD suggests this is a complex relationship (Santos \& Stuart, 2003) and changes in coachee behaviour and attitudes may not directly contribute to better outcomes for employers.

Blackman's (2006) study asked coachees to list their personal goals for the coaching program they were involved in and the goals they thought their organization might have for the coaching and found there was little overlap between the two. It is possible that an effective coaching program helps the coachee reach their personal goals which may then lead to them leaving the organization. This is supported by a consistent finding across a number of studies (see Gegner, 1997 for an example) where coaching was seen as contributing to a 
number of personal benefits outside the workplace such as improved family communication and a better work-life balance resulting from better time management at work. The review reveals an interesting tension within coaching that has been given little attention to date the tension between the effectiveness of the coaching for the individual coachee versus the benefits and outcomes for the organisation. It is possible that measures of coaching effectiveness that focus solely on elements such as ROI and productivity within the workplaces may not capture all the outcomes of value to the coachee.

\section{Research Question 2: Business coaching compared to other techniques}

Much of the research reported in the 111 studies was conducted on specific coaching programs, often run by one of the researchers and so there was little systematic comparative research. As a result there was no clear evidence that coaching was more effective than other training or development techniques and a tendency to assume that if participants rated the coaching as effective that this was defacto evidence of its effectiveness over other techniques. One study did, however, find evidence that when coaching was combined with other more traditional development options then there was a significant increase in coachee productivity when compared to the traditional option alone (Olivero et al., 1997). This suggests that coaching may be an important tool to assist in the transfer of learning from the development options. However, further studies are clearly needed in this area.

\section{Research Question 3: Factors contributing to effective outcomes}

The studies reviewed for this question were organised into a set of themes that emerged from the results and conclusions reported in the individual papers. The identification of these themes followed the same steps as used in content analysis and thematic coding for developing grounded theory (Grbich, 2013). The resulting themes are discussed in more 
detail in the following sections but are very similar to those proposed by Cox et al (2014) in their structural analysis of coaching.

\section{Characteristics and Behaviours of Effective Coaches}

The findings with regard to effective coach characteristics and skills across the three groups of studies reviewed can be summarised into four consistent themes - integrity, support for the coachee, communication skills (Rekalde, Landeta, \& Albizu, 2015) and behaviours, and credibility. Important elements of integrity were trustworthiness (Blattner, 2005; Graham, Wedman, \& Garvin-Kester, 1994; Gregory \& Levy, 2011; Judge \& Cowell, 1997; Kombarakaran, Yang, Baker, \& Fernandes, 2008; Kralj, 2001; O'Brion \& Palmer, 2010; Orenstein, 2006; Peterson, 1996; Rekalde et al., 2015) and maintenance of confidentiality (Blackman, 2010; Douglas \& McCauley, 1999; Rekalde et al., 2015; Segers, Vloeberghs, Henderickx, \& Inceoglu, 2011; Taie, 2011). Support for the coachee included empathy (De Haan, Culpin, \& Curd, 2011; Gregory \& Levy, 2011) being non-judgemental (Blackman, 2010; Judge \& Cowell, 1997), and being able to put issues into a larger perspective (Ahern, 2003; Graham et al., 1994; Orenstein, 2006; Styhre \& Josephson, 2007). Communication skills were particularly important (Graham et al., 1994; Longenecker, 2010; Rekalde et al., 2015; Thach, 2002) with particular significance attached to the provision of clear performance expectations (Ahern, 2003; Graham et al., 1994; Orenstein, 2000) and detailed and regular feedback (De Haan, 2008b; Graham et al., 1993, 1994; Gregory \& Levy, 2011; Judge \& Cowell, 1997; Karsten, 2010; Longenecker, 2010; Miller, 2003; Olivero et al., 1997; Orenstein, 2006; Strayer \& Rossett, 1994; Taie, 2011; Wasylyshyn, 2003). In the case of these first three themes the conclusions are consistent with those made by Joo (2005) and Passmore and Fillery-Travis (2011). 


\section{Characteristics of the Coachee}

In comparison to the coach, the coachee has been given far less attention in research to date. The review found some limited evidence that coachee motivation expressed through amount of effort invested and an open attitude to change (Audet \& Couteret, 2012) in the coaching and self-efficacy are important characteristics linked to positive coaching outcomes (Anderson, 2013; Baron \& Morin, 2010; Berg \& Karlsen, 2012; Blackman, 2006; Bozer, Sarros, \& Santora, 2013; De Haan, Duckworth, Birch, \& Jones, 2013; Levy et al., 2002). It is important to note that most, but not all, of the coachees in the 111 studies reviewed were high achievers and/or took on the coaching voluntarily, suggesting little variation in motivation and confidence was available to be examined limiting conclusions. There was some evidence, however, that even within this group there were factors that acted as barriers to coachees' being able to invest as much time and effort into the process as desired (Blackman, 2006). These included family commitments and an inability to find time in the existing workload.

There has also been some debate in the literature about who is likely to benefit the most from coaching with some authors linking coaching to the development of leaders and managers (Caligiuri, 2006; Riggio \& Lee, 2007) and others arguing that coaching is particularly useful for new, young and less experienced staff (Feldmen, 1995). The studies reviewed included a wide range of coachees, from different sectors and at different levels of experience and seniority, and there was no evidence that any one type of coachee benefited more than the others.

\section{Features of the Coach-Coachee Relationship}

Two consistent themes emerged from the review with regard to the coach-coachee relationship. The first theme was the need to find a good match between coachee and coach (Ahern, 2003; Brodie Gregory \& Levy, 2012; De Haan, 2008b; Gan \& Chong, 2015; Graham et 
al., 1994; Gray \& Goregaokar, 2010; G. Jones \& Spooner, 2006; Peterson \& Millier, 2005; Wasylyshyn, 2003; Wasylyshyn et al., 2006). Few details were provided though on what was required to make a good match. The second theme was that coachees believed that better outcomes were more likely when the coach developed an individual or personalised program for the coachee (Blackman, 2010; Blattner, 2005; Gregory \& Levy, 2011; Kiel, Rimmer, Williams, \& Doyle, 1996; Orenstein, 2006; Peterson, 1996; Wasylyshyn et al., 2006; Winum, 2005).

\section{Elements of the Coaching Process}

The majority of the reviewed studies examined specific coaching programs in detail and so it is not surprising to find that the largest number of results related to the required or important features of the coaching process. These features included:-

- Establishing the benefits of coaching at the start of the program (Baron \& Morin, 2010; Bond \& Seneque, 2013);

- A focus on setting clear goals or outcomes to be achieved (Baron \& Morin, 2010; Blackman, 2008, 2010; De Haan et al., 2011; Evers et al., 2006; AM Grant, Green, \& Rynsaardt, 2010; Gray et al., 2011; Judge \& Cowell, 1997; Moen \& Federici, 2012; Orenstein, 2006; Scriffignano, 2011; Smither et al., 2003; van Oorsouw, Embregts, \& Bosman, 2013);

- Providing coachees with a clear understanding of their strengths and weaknesses and an action plan for resolving issues (Judge \& Cowell, 1997);

- Using coaching with other forms of organisational consultation (Sauer, 1999);

- Regular communication and contact between the coach and coachee (Jowett, Kanakoglou, \& Passmore, 2012; Sauer, 1999); 
- Maintaining a long term focus (Gan \& Chong, 2015; AM Grant et al., 2010; Hall et al., 1999; Judge \& Cowell, 1997; Styhre, 2008);

- A focus on continuous learning (Cleary \& Zimmerman, 2004; De Haan \& Nieb, 2012; Douglas \& McCauley, 1999; Scherer, Canty, Peterson, \& Cooper, 1995; Strayer \& Rossett, 1994); and

- Ongoing evaluation of progress so the program can be adjusted (Cleary \& Zimmerman, 2004; Olivero et al., 1997).

\section{Features of the Organizational Context}

The main theme in the results relevant to the organizational context was that the coachee's employment organization needs to share the responsibility for the coaching goals and outcomes (Peterson, 1996; Wasylyshyn et al., 2006). This can be achieved through adopting a number of change programs (Kombarakaran et al., 2008; Schnell, 2005), including working on aligning individual and organisational goals (Kim et al., 2013; McGurk, 2011; Winum, 2005), providing support to the coachee to engage in the program (Kombarakaran et al., 2008; Levenson, 2009; Orenstein, 2006; Rocereto, Mosca, Forquer Gupta, \& Rosenberg, 2011; Smith Glasgow et al., 2009; Winum, 2005), ensuring commitment from senior management for the coaching program (Baron \& Morin, 2010; Blackman, 2010; Gray et al., 2011; Smither et al., 2003) and providing an appreciative environment (Maritz, 2013).

\section{Research Question 4: Understanding coach credibility}

Research Question 4 focused on the evidence available to inform key debates on the factors that affect coach credibility. While there is agreement that coaches must be seen as credible to be effective (Joo, 2005; Judge \& Cowell, 1997; Passmore \& Fillery-Travis, 2011; Segers et al., 2011; Sue-Chan \& Latham, 2004), there is debate around how this credibility can be established. This debate has been between those who believe that coaches do not 
need skills or expertise in the management or organisation sector in which they work but rather need skills in counselling psychology or therapy (Ajzen, 1992; Beutler, Machado, \& Neufeldt, 1994; Lafferty, Beutler, \& Crago, 1989; Petty \& Cacioppo, 1984), and those who argue that coaches must have skills or expertise in either executive management development and/or in the sector in which they are practising (Berglas, 2002; Eggers \& Clark, 2000; Evers et al., 2006; Hagen, 2010; Joo, 2005; Passmore \& Fillery-Travis, 2011; Smither et al., 2003; VanFleet, 1999). The evidence available in the 111 studies reviewed here tends towards the latter conclusion, that skills or expertise in the sector or in executive management are preferable (De Haan, 2008a; Judge \& Cowell, 1997; Kiel et al., 1996; Orenstein, 2006; Smith Glasgow et al., 2009; Wasylyshyn, 2003). There was also support for the idea that credibility and effectiveness is enhanced by a coach external to the organisation that the coachee works for (De Haan, 2008a; Judge \& Cowell, 1997; Oberschachtsiek \& Scioch, 2015).

\section{DISCUSSION}

The Introduction section to the present paper established five key questions to guide this review. For each question, this summary provides an overall conclusion noting consistency with previous reviews, highlighting new knowledge generated by this review and suggests directions for future research.

The first question addressed in the review was whether or not business coaching was an effective development tool and in what areas was it particularly effective. The review established some preliminary evidence that business coaching can be effective across a range of different outcomes. This evidence was limited however to participants' selfreported evaluations. Despite numerous discussions in the literature about desirable methodologies for evaluating effectiveness, and a significant increase in the number of studies being conducted into coaching, there has been little change in the approaches taken 
in the published research. These conclusions are consistent with those of previous reviews (Ely et al., 2010; Feldmen \& Lankau, 2005; Joo, 2005; Passmore \& Fillery-Travis, 2011; Passmore \& Gibbes, 2007).

The present review identified, however, a new issue for consideration - the tension between coaching benefits for the individual coachee and coaching benefits for the organisation and, indeed, society. This tension arises from elements unique to coaching which are linked to taking a holistic perspective and a focus on the individual and their goals and perspectives and has been given little attention in previous literature. Research is needed that more explicitly measures coachees' goals and how consistent these are with the organisational goals. These then need to be compared for possible variations and differences of perceived coaching effectiveness. Kaufman and Keller (1994) add to Kirkpatrick's (1959) four levels of evaluation with a fifth, advising that interventions need to take account of their broader impact on society.

It has also been suggested that business coaching is more effective than other forms of training and development. For example, some authors have argued that business coaching provides better transfer of training to the workplace than other techniques because it is grounded in the coachee's workplace (Bacon \& Spear, 2003; Eggers \& Clark, 2000; Joo, 2005; Olivero et al., 1997). Similarly, Van Velsor and Leslie (1995), argue that coaching avoids problems of overdependence that can be a problem with mentoring and Day (2001) concludes that coaching is preferable to job assignment because coaching addresses overall development and is not limited to a particular set of skills. The second question asked whether business coaching was more effective than other training or development options. The review of 111 empirical studies did not find any clear evidence that business coaching was a more effective staff development option. Again, this was not a novel conclusion. The process used in the present review of dividing the studies into categories based on 
approaches to research design used did identify a number of studies where coaching was part of a larger training program. As a result there was some emerging evidence that coaching may be useful to assist transfer of learning from other training options. This conclusion prompts a call for more research into the instructional learning aspects of coaching and that future research needs to adopt more field experimental techniques to systematically compare coaching to other training and development options.

The third question sought the factors that contribute to effective coaching. In addition to the claims made about the effectiveness of business coaching overall, there are also numerous claims made about the details or the characteristics of coaching that contribute to this effectiveness. Figure 1 provides a summary of the most common claims made in this area organised under headings of characteristics of the coach, the coachee, the coaching practice, the coach-coachee relationship and the wider context or barriers. The framework is consistent with that used in previous reviews (Bennet, 2006; Passmore \& Fillery-Travis, 2011) and is based on Kilburg's (2001) analysis of coaching practice. Webster and Watson (2002) argue that the use of such a framework is preferable to an historical or annotated bibliographic review style as it allows for clearer links to be made to potential concepts and theories. There is consensus that in the case of coaches, integrity, support for the coachee and good communication skills are critical characteristics and these features have been noted in previous reviews (Passmore \& Fillery-Travis, 2011). The results of our systematic review outline the empirical support found by Maltbia et al (2014) remembering that overall the evidence of effectiveness is limited in many or the studies reviewed. In addition Maltbia et al (2014)offered quite specific direction as to particular communication skills necessary for effective coaching and the available studies rarely examined the feature of communication in detail. This offers an opportunity for additional research that analyses the proposed competencies in more detail. 


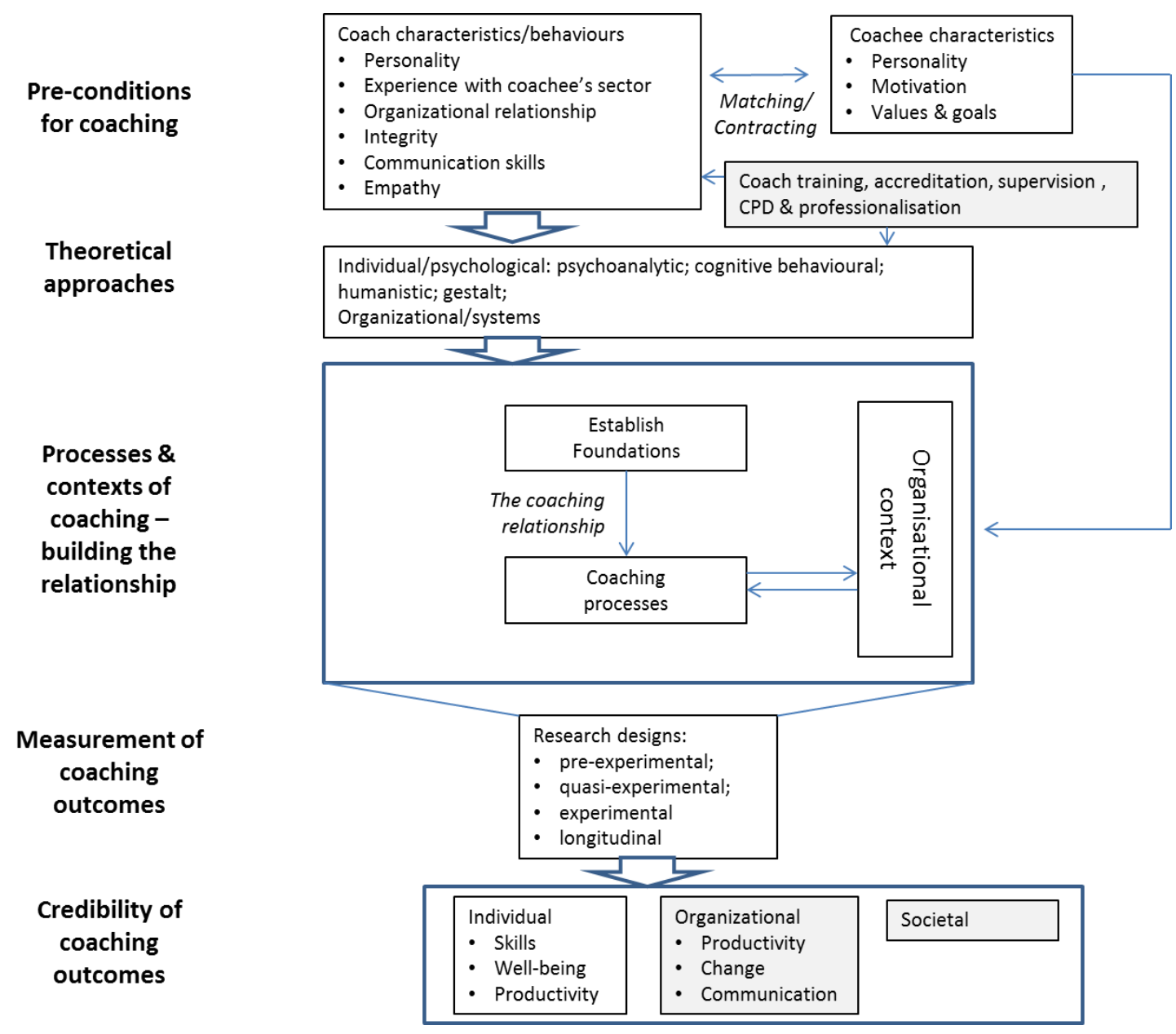

Figure 1 Conceptual framework

The fourth question sought to explore the factors that contribute to the credibility of coaching. The present review found evidence and an area for future research suggesting that credibility is enhanced by expertise in the relevant business sector and by being external to the coachee's work organisation. While anecdotal accounts of positive personal experiences of coaching abound, the long-term credibility of coaching must rely on evidence-based studies based on robust research, including quasi-experimental and experimental designs based on both cross-sectional and longitudinal designs.

The fifth question was about gaps in the existing research and despite a considerable increase in the number of empirical papers published, few of the gaps identified in previous reviews have been addressed. More specifically, there continues to be a need for research 
that assesses the effectiveness of coaching using measures other than subjective evaluations from participants and that uses valid experimental methods, to better understand the impact of coachee versus organisational goals on the coaching experience. Research into coaching effectiveness also needs to explore longer term outcomes as well as immediate impacts using longitudinal rather than cross-sectional research designs. De Meuse et al. (2009) and Ely et al. (2010) offer more details on suggested methodologies. These methodologies also need to be applied to studies that systematically examine the effectiveness of coaching relative to other training or development options.

Overall this review can be summarized in a comprehensive conceptual framework see Figure 2 that also shows the areas that offer opportunities for delivering evidence-based improvements. This can include options for improving processes and their interface with organizational contexts and identifies pre-conditions for coaching effectiveness.

\begin{tabular}{|c|c|c|c|c|}
\hline Coach & Coachee & Relationship & & $\begin{array}{l}\text { Coaching } \\
\text { Process }\end{array}$ \\
\hline $\begin{array}{l}\text {-Experience } \\
\text { with coaching } \\
\text { - Experience } \\
\text { with relevant } \\
\text { sector } \\
\text { - Likeable } \\
\text { - Self-confident } \\
\text { - Empathetic } \\
\text { - Warm } \\
\text { - Organised } \\
\text { - Creative } \\
\text { - Calm } \\
\text { - Communicate } \\
\text { s clearly } \\
\text { - Honest } \\
\text { - Maintains } \\
\text { confidentialit }\end{array}$ & $\begin{array}{l}\text { - Self-efficiacy } \\
\text { - Motivated } \\
\text { - Locus of } \\
\text { control } \\
\text { - Confident } \\
\text { - Committed } \\
\text { - Involved } \\
\text {-Effort } \\
\text {-Ability/compe } \\
\text { tence }\end{array}$ & $\begin{array}{l}\text { - Matching } \\
\text { between } \\
\text { coach and } \\
\text { coachee } \\
\text { - One-on-one } \\
\text { interaction } \\
\text { - Trust } \\
\text { - Authenticity } \\
\text { - Challenge } \\
\text { - Commitment } \\
\text { by both }\end{array}$ & $\begin{array}{l}\text {-Support } \\
\text { - Goal alignment }\end{array}$ & $\begin{array}{l}\text { - Encourage } \\
\text { appropriate } \\
\text { action } \\
\text { - Uses priorities } \\
\text { and timelines } \\
\text { - Relates } \\
\text { personal to } \\
\text { organisational } \\
\text { goals } \\
\text { - Identifies } \\
\text { blind spots } \\
\text { - Constructively } \\
\text { views difficult } \\
\text { issues }\end{array}$ \\
\hline
\end{tabular}

Figure 2: Summary of Factors Contributing to Effective Coaching Practice 


\section{CONCLUSIONS}

The present paper sought a unique approach to critically examining the issue of coaching effectiveness using a SRm which has not been used previously in the business coaching literature. This approach supported a more comprehensive and focused review incorporating a larger body of empirical evidence than has previously been examined in narrative or meta-analytic reviews. Given the dramatic increase in academic empirical studies evident in recent years, the present review provides an assessment of the effectiveness of coaching based on a larger body of empirical evidence than was previously available, a comprehensive overview of the field that is not limited by a specific focus on one aspect of coaching.

After completing the systematic review a number of reasons can be put forward to explain the lack of progress in the coaching research reviewed in this paper. Firstly, there are practical barriers. Many studies are conducted by coach practitioners in real world settings making it difficult and often unethical to randomly assign participants to different experimental and control conditions. Even where quasi-experimental designs can be developed, they are likely to involve longer time frames and the employer organisations may be reluctant to fund coaching programs in these situations. The current state of coaching reflects a continuing concern amongst researchers involved with establishing coaching as a legitimate HRD activity and with the development of coaches as professionals. To mature as a field, the research needs to move beyond these concerns and focus on developing sound theoretical models based on more sophisticated research.

Webster and Watson (2002), in their guide to good research reviews, caution against being overly critical of an area and this seems particularly pertinent to the field of coaching research. It would be easy to suggest that despite a significant increase in the number of empirical studies little actual progress has been made in demonstrating the effectiveness of 
coaching or providing guidelines for coaching practice. Alternatively it could be argued that the growth in studies that evaluate coaching programs in a number of sectors and locations suggest that coaching has now established itself as a legitimate HR development tool and that coaching programs can be positively evaluated by a variety of participants and methods. The present challenge for researchers in this area is to accept this conclusion and begin to examine coaching in more detail and with a more critical approach. This paper offers direction for a more evidence based conceptual framework to guide future research and practice. 


\section{References}

Ahern, G. (2003). Designing and implementing coaching/mentoring competencies: A case study. Counselling Psychology Quarterly, 16(4), 373-383.

Ajzen, I. (1992). Persuasive communication theory in social psychology. In M. Manfredo (Ed.), Influencing human behavior (pp. 1-28). Champaign, IL: Sagamore Publishing.

Anderson, V. (2013). A Trojan Horse? The implications of managerial coaching for leadership theory. Human Resource Development International, 1-16. doi: $10.1080 / 13678868.2013 .771868$

Audet, J., \& Couteret, P. (2012). Coaching the entrepreneur: Features and success factors. Journal of Small Business and Enterprise Development, 19(3), 515-531.

Bachirova, T., Cox, E., \& Clutterbuck, D. (2014). Introduction. In E. Cox, T. Backirova, \& D. Clutterbuck (Eds.), The complete handbook of coaching (2nd ed ed., pp. 1-20). London: Sage.

Bacon, T., \& Spear, K. (2003). Adaptive coaching: The art and practice of a client-centered approach to performance improvement. Palo Alto, CA: Davies-Black.

Baron, L., \& Morin, L. (2010). The impact of executive coaching on self-efficacy related to management soft-skills. Leadership \& Organization Developement Journal, 31(1), 1838.

Bartlett II, J., Boylan, R., \& Hale, J. (2014). Executive coaching: An integrative literature review. Journal of Human Resource and Sustainability Studies, 2(04), 188-195.

Beattie, R. S., Kim, S., Hagen, M. S., Egan, T. M., Ellinger, A. D., \& Hamlin, R. G. (2014). Managerial Coaching: A review of the Empirical Literature and Development of a Model to Guide Future Practice. Advances in Developing Human Resources, 16(2), 184-201.

Bennet, J. (2006). An agenda for coaching-related research: A challenge for researchers. Consulting Psychology Journal: Practice and Research, 58(4), 240-249.

Berg, M., \& Karlsen, J. (2012). An evaluation of management training and coaching. Journal of Workplace Learning, 24(3), 177-199.

Berglas, S. (2002). The very real dangers of executive coaching. Harvard Business Review, 80(6), 86-92.

Beutler, L., Machado, P., \& Neufeldt, S. (1994). Therapist variables. In A. Bergin \& S. Garfield (Eds.), Handbook of psychotherapy and behavior change (4th ed., pp. 229-269). New York: Wiley.

Blackman, A. (2006). Factors that contribute to the effectiveness of business coaching: The coachees perspective. The Business Review, Cambridge, 5(1), 98-104.

Blackman, A. (2008). Perspectives on leadership coaching for regional tourism managers and entrepreneurs In G. Moscardo (Ed.), Building Community Capacity for Tourism Development (pp. 142-154). Wallingford: CABI.

Blackman, A. (2010). Coaching as a leadership development tool for teachers. Professional Development in Education, 36(3), 421-441.

Blattner, J. (2005). Coaching: The successful adventure of a downwardly mobile executive Consulting Psychology Journal: Practice and Research, 57(1), 3-13.

Bond, C., \& Seneque, M. (2013). Conceptualizing coaching as an approach to management and organizational development. Journal of Management Development, 32(1), 5772.

Bozer, G., Sarros, J., \& Santora, J. (2013). The role of coachee characteristics in executive coaching for effective sustainability. Journal of Management Development, 32(3), 277-294.

Bozer, G., Sarros, J., \& Santora, J. (2014). Academic background and credibility in executive coaching effectiveness. Personnel Review, 43(6), 881-897. 
Brandl, J., Madsen, M., \& Madsen, H. (2009). The perceived importance of HR duties to Danish line managers. Human Resource Management Journal, 19(2), 194-210.

Briner, R., \& Denyer, D. (2012). Systematic review and evidence sythesis as a practice and scholarship tool. In D. Rousseau (Ed.), The Oxford handbook of evidence-based management: Companies, classrooms and research (pp. 112-129). Oxford: Oxford University Press.

Brodie Gregory, J., \& Levy, P. (2012). Employee feedback orientation: implications for effective coaching relationships. Coaching: An International Journal of Theory, Research and Practice, 5(2), 86-99.

Caligiuri, P. (2006). Developing global leaders. Human Resource Management Review, 16, 219-228.

Capuzzi Simon, C. (2003). A coach for team 'you' Washington Post Online. Retrieved from: http://www.hscareers.com/news/articles.asp?id=478

Cleary, T., \& Zimmerman, B. (2004). Self-regulation empowerment program: A school-based program to enhance self-regulated and self-motivated cycles of student learning. Psychology in the Schools, 41(5), 537-550.

Corey, G. (2012). Theory and practice of counselling and psychotherapy (9th ed.). Belmont: Brooks/Cole.

Cox, E., Bachkirova, T., \& Clutterbuck, D. (2014). Theoretical traditions and coaching genres: Mapping the territory. Advances in Developing Human Resources, 16(2), 139-160.

Day, D. (2001). Leadership development: A review in context. Leadership Quarterly, 11(4), 581-613.

De Haan, E. (2008a). I doubt therefore I coach: Critical moments in coaching practice. Consulting Psychology Journal: Practice and Research, 60(1), 91-105.

De Haan, E. (2008b). I struggle and emerge: Critical moments of experienced coaches. Consulting Psychology Journal: Practice and Research, 60(1), 106-131.

De Haan, E., Culpin, V., \& Curd, J. (2011). Executive coaching in practice: What determines helpfulness for clients of coaching? Personnel Review, 40(4), 24-44.

De Haan, E., Duckworth, A., Birch, D., \& Jones, C. (2013). Executive coaching outcome research: The contribution of common factors such as relationship, personality match, and self-efficacy. Consulting Psychology Journal Practice and Research, 65(1), 40-57.

De Haan, E., \& Nieb, C. (2012). Critical moments in a coaching case study: Illustration of a process research model. Consulting Psychology Journal Practice and Research, 64(3), 198-224.

De Meuse, K., Dai, G., \& Lee, R. (2009). Evaluating the effectiveness of executive coaching: Beyond ROI? Coaching: An International Journal of Theory, Research and Practice, 2(2), 117-134.

Denyer, D., \& Tranfield, D. (2009). Producing a systematic review. In D. Buchanan \& A. Bryman (Eds.), The SAGE Handbook of Organizational Research Methods (pp. 671689). London: Sage.

Diedrich, R., \& Kilburg, R. (2001). Further consideration of executive coaching as an emerging competency. Consulting Psychology Journal: Practice and Research, 53(4), 203-204.

Doorewaard, H., \& Meihuizen, H. (2000). Strategic performance options in professional service organisations. Human Resource Management Journal, 10(2), 39-57.

Douglas, C., \& McCauley, C. (1999). Formal developmental relationships: A survey of organizational practices. Human Resource Development Quarterly, 10(3), 203-220.

Dyck, B., \& Neubert, M. (2010). Management: Current practices and new directions. Boston, MA: Houghton Mifflin Harcourt

Eggers, J., \& Clark, D. (2000). Executive coaching that wins. Ivey Business Journal, 65(1), 6671. 
Ellinger, A. D., Ellinger, A. E., \& Keller, S. B. (2003). Supervisory coaching behavior, employee satisfaction, and warehouse employee performance: A dyadic perspective in the distribution industry. Human Resource Development Quarterly, 14(4), 435-458.

Ely, K., Boyce, L., Nelson, J., Zaccaro, S., Hernez-Broome, G., \& Whyman, W. (2010). Evaluating leadership coaching: A review and integrated framework. Leadership Quarterly, 21, 585-599.

Evers, W., Brouwers, A., \& Tomic, W. (2006). A Quasi-experimental study on management coaching effectiveness. Consulting Psychology Journal: Practice and Research, 58(3), 174-182.

Feldmen, D. (1995). The impact of downsizing on organisational career development activities and employee career development opportunities. Human Resource Management Review, 5(189-221).

Feldmen, D., \& Lankau, M. (2005). Executive coaching: A review and agenda for future research. Journal of Management, 31(6), 829-848.

Fillery-Travis, A., \& Lane, D. (2006). Does coaching work or are we asking the wrong questions? International Coaching Psychology Review, 1(1), 23-36.

Foster, S., \& Lendl, J. (1996). Eye movement desensitization and reprocessing: Four case studies of a new tool for executive coaching and restoring employee performance after setbacks. Consulting Psychology Journal: Practice and Research, 48(3), 155-161.

Fournies, F. (1999). Why employees don't do what they are supposed to do and what to do about it. New York: McGraw-Hill.

Fulmer, R., Gibbs, P., \& Goldsmith, M. (2000). Developing Leaders: How winning companies keep on winning. Sloan Management Review, 42(1), 49.

Gan, G. C., \& Chong, C. W. (2015). Coaching relationship in executive coaching: a Malaysian study. Journal of Management Development, 34(4), 476-493.

Garvey, R., Stokes, P., \& Megginson, D. (2009). Coaching and Mentoring: Theory and Practice. London: Sage.

Gatling, A., Castelli, P., \& Matthew, C. (2013). Authentic leadership: The role of self awareness in promoting coaching effectiveness. Asia-Pacific Journal of Management Research and Innovation, 9(4), 337-347.

Gegner, C. (1997). Coaching: Theory and practice. (Unpublished master's thesis), University of San Francisco, San Francisco, CA.

Graham, S., Wedman, J., \& Garvin-Kester, B. (1993). Manager coaching skills: Development and application. Performance Improvement Quarterly, 6(1), 2-13.

Graham, S., Wedman, J., \& Garvin-Kester, B. (1994). Manager coaching skills: What makes a good coach. Performance Improvement Quarterly, 7(2), 91-104.

Grant, A. (2001). Towards a Psychology of Coaching. unpbulished manuscript. Coaching Psychology Unit, School of Psychology. University of Sydney.

Grant, A. (2005a). Theories and techniques of coaching psychology: PSYC 4721 Lecture 1 (pp. 16-33). Sydney: Coaching Psychology Unit, School of Psychology, University of Sydney, Australia.

Grant, A. (2005b). Workplace, executive and life coaching: An annotated bibliography from the behavioural science literature (pp. 1-39). Sydney: Coaching Psychology Unit, University of Sydney, Australia.

Grant, A. (2011). Workplace, executive and life coaching: An annotated bibliography from the behavioural science and business literature. Coaching Psychology Unit. University of Sydney. Sydney. Retrieved from Retrieved from http://groupspaces.com/AustralianCoachingIndustryRese/pages/coachingannotated-bibliography-from-peer-reviewed-literature-1935-2011 
Grant, A., Green, L., \& Rynsaardt, J. (2010). Developmental coaching for high school teachers: Executive coaching goes to school. Consulting Psychology Journal: Practice and Research, 62(3), 151-168.

Gray, D., Ekinci, Y., \& Goregaokar, H. (2011). Coaching SME managers: Business development or personal therapy? A mixed methods study. The International Journal of Human Resource Management, 22(4), 863-882.

Gray, D., Garvey, B., \& Lane, D. (2016). Critical introduction to coaching and mentoring. London: Sage.

Gray, D., \& Goregaokar, H. (2010). Choosing an executive coach: The influence of gender on the coach-coachee matching process. Management Learning, 41(5), 525-544.

Grbich, C. (2013). Qualitative data analysis: An introduction. London: Sage.

Gregory, J., \& Levy, P. (2011). It's not me, it's you: A multilevel examination of variables that impact employee coaching relationships. Consulting Psychology Journal: Practice and Research, 63(2), 67-88.

Hagen, M. (2010). Black belt coaching and project outcomes: An empirical investigation. The Quality Mangement Journal, 17(2), 54-67.

Hagen, M., \& Garvrilova Aguilar, M. (2012). The impact of managerial coaching on learning outcomes with the team context: An analysis. Human Resource Development Quarterly, 23(3), 363-388.

Hagen, M., \& Peterson, S. (2014). Coaching scales a review of the literature and comparative analysis. Advances in Developing Human Resources, 16(2), 222-241.

Hall, D., Otazo, K., \& Hollenback, G. (1999). Behind closed doors. Organizational Dynamics, 27(3), 39-53.

Harris, M. (1999). Look, it's an I-O psychologist...no, it's a trainer...no, it's an executive coach. TIP, 36(3), 1-5.

Hawkins, P., \& Smith, N. (2013). Coaching, mentoring and organizational consultancy: Supervision, skills \& development. (2nd ed.). Maidenhead: OUP.

Hudson, F. (1999). The handbook of coaching. San Francisco: Jossey-Bass.

Jarvis, J. (2004). Coaching and buying coaching services. London: CIPD.

Jarvis, J., Lane, D., \& Fillery-Travis, A. (2006). Does coaching work? London: CIPD.

Jones, G., \& Spooner, K. (2006). Coaching high achievers. Consulting Psychology Journal: Practice and Research, 58(1), 40-50.

Jones, M., Coviello, N., \& Tang, Y. (2011). International entrepreneurship research (19892009): a domain ontology and thematic analysis. Journal of Business Venturing, 26(6), 632-659.

Jones, R., Woods, S., \& Guillaume, Y. (2015). The effectiveness of workplace coaching: A meta-analysis of learning and performance outcomes from coaching. Journal of Occupational and Organizational Psychology. doi: DOI: 10.1111/joop.12119

Joo, B. (2005). Executive coaching: A conceptual framework from an integrative review of practice and research. Human Resource Development Review, 4(4), 462-488.

Jowett, S., Kanakoglou, K., \& Passmore, J. (2012). The application of the $3+1$ Cs relationship model in executive coaching. Consulting Psychology Journal Practice and Research, 64(3), 183-197.

Judge, W., \& Cowell, J. (1997). The brave new world of executive coaching. Business Horizons, 40(4), 71.

Kampa-Kokesch, S., \& Anderson, M. (2001). Executive coaching: A comprehensive review of literature. Consulting Psychology Journal: Practice and Research, 53(4), 205-228.

Karsten, M. (2010). Coaching: An effective leadership intervention. Nursing Clinics of North America, 45(1), 39-48.

Kaufman, R., \& Keller, J. (1994). Levels of evaluation: Beyond Kirkpatrick. Human Resource Development Quarterly, 5(4), 371-380. 
Keupp, M., Palmié, M., \& Gassmann, O. (2012). The strategic management of innovation: a systematic review and paths for future research. International Journal of Management Reviews, 14(4), 367-390.

Kiel, F., Rimmer, E., Williams, K., \& Doyle, M. (1996). Coaching at the top. Consulting Psychology Journal: Practice and Research, 48(2), 67-77.

Kilburg, R. (1996a). Executive coaching as an emerging competency in the practice of consultation. Consulting Psychology Journal: Practice and Research, 48(2), 59-60.

Kilburg, R. (1996b). Toward a conceptual understanding and definition of executive coaching. Consulting Psychology Journal: Practice and Research, 48(2), 134-144.

Kilburg, R. (2001). Facilitating intervention adherence in executive coaching: A model and methods. Consulting Psychology Journal: Practice and Research, 53(4), 251-267.

Kilburg, R. (2004). Trudging toward Dodoville:Conceptual approaches and case studies in executive coaching. Consulting Psychology Journal: Practice and Research, 56(4), 203-211.

Kim, S., Egan, T. M., Kim, W., \& Kim, J. (2013). The impact of managerial coaching behavior on employee work-related reactions. Journal of Business and Psychology, 28(3), 315330.

Kirkpatrick, D. (1959). Techniques for evaluating training programs. Journal of American Society of Training Directors, 13(3), 21-26.

Kombarakaran, F., Yang, J., Baker, M., \& Fernandes, P. (2008). Executive coaching: It works! Consulting Psychology Journal: Practice and Research, 60(1), 78-90.

Konczak, L., Stelly, D., \& Trusty, M. (2000). Defining and measuring empowering leader behaviors: Development of an upward feedback instrument. Educational \& Psychological Measurement, 60(2), 301-313.

Kralj, M. (2001). Coaching at the top: Assisting a chief executive and his team. Consulting Psychology Journal: Practice and Research, 53(2), 108-116.

Ladergard, G. (2011). Stress management through workplace coaching: The impact of learning experiences. International Journal of Evidence Based Coaching and Mentoring, 9(1), 29-43.

Lafferty, P., Beutler, L., \& Crago, M. (1989). Differences between more and less effective psychotherapists: A study of select therapist variables. Journal of Consulting and Clinical Psychology, 57, 76-80.

Lauer, J., \& Asher, W. (1988). Composition research: Empirical designs. New York: Oxford University Press.

Leedham, M. (2005). The coaching scorecard: A holistic approach to evaluating the benefits of business coaching. International Journal of Evidence Based Coaching and Mentoring, 3(2), 30-44.

Levenson, A. (2009). Measuring and maximizing the business impact of executive coaching. Consulting Psychology Journal: Practice and Research, 61(2), 103-121.

Levy, P., Cober, R., \& Miller, T. (2002). The effect of transformational and transactional leadership perceptions on feedback-seeking intentions. Journal of Applied Social Psychology, 32(8), 1703-1720.

Liljenstrand, A., \& Nebeker, D. (2008). Coaching services: A look at coaches, clients, and practices. Consulting Psychology Journal: Practice and Research, 60(1), 57-77.

Longenecker, C. (2010). Coaching for better results: key practices of high performance leaders. Industrial and Commercial Training, 42(1), 32-40.

Lowman, R. (2005). Executive coaching: The road to Dodoville needs paving with more than good assumptions. Consulting Psychology Journal: Practice and Research, 57(1), 9096. 
Maltbia, T., Marsick, V., \& Ghosh, R. (2014). Executive and organizational coaching: A review of insights drawn from literature to inform HRD practice. Advances in Developing Human Resources,, 16(2), 161-183.

Maritz, J. (2013). Taming the wild west of business coaching training: An emerging conceptual framework. Acta Commercii, 13(1), 1-11.

McDermott, M., Levenson, A., \& Newton, S. (2007). What coaching can and cannot do for your organization Human Resource Planning, 30(2), 30-37.

McGovern, J., Lindemann, M., Vergara, M., Murphy, S., Barker, L., \& Warrenfeltz, R. (2001). Maximizing the impact of executive coaching: Behavioral change, orgnaizational outcomes, and return on investment. The Manchester Review, 6(1), 1-9.

McGurk, J. (2011). Real-world coaching evaluation. Training Journal(Feburary), 70-74.

Miller, P. (2003). Workplace learning by action learning: A practicle example. Journal of Workplace Learning: Employee Counselling Today, 15(1), 14-23.

Moen, F., \& Federici, R. (2012). The effect from external executive coaching. Coaching: An International Journal of Theory, Research and Practice, 5(2), 113-131.

Natale, S., \& Diamante, T. (2005). The five stages of executive coaching: Better process makes better practice. Journal of Business Ethics, 59, 361-374.

Norlander, T., Bergman, H., \& Archer, T. (2002). Relative constancy of personality characteristics of a 12-month training program facilitating coping strategies. Social Behavior and Personality, 30(8), 773-783.

O'Brion, A., \& Palmer, S. (2010). Exploring key aspects in the formation of coaching relationships: Initial indicators from the perspective of the coachee and the coach. Coaching: An International Journal of Theory, Research and Practice, 3(2), 124-143.

O'Neil, J., \& Marsick, V. (2014). Action Learning Coaching. Advances in Developing Human Resources, 16(2), 202-221.

Oberschachtsiek, D., \& Scioch, P. (2015). The outcome of coahcing and training for selfemployment. A statistical evaluation of outside assistance support programs for unemployed business founders in Germany. Journal for Labour Market Research, 48(1), 1-25.

Olesen, M. (1996). Coaching today's executives. Training and Development Journal, 50(3), 22-27.

Olivero, G., Denise Bane, K., \& Kopelman, R. (1997). Executive coaching as a transfer of training tool: Effects on productivity in a public agency. Public Personnel Management, 26(4), 461-469.

Orenstein, R. (2000). Executive coaching: An intergrative model. Dissertation Abstracts International, 61/04, 2257.

Orenstein, R. (2006). Measuring executive coaching efficacy? The answer was right here all the time. Consulting Psychology Journal: Practice and Research, 58(2), 106-116.

Parker-Wilkins, V. (2006). Business impact of executive coaching: Demonstrating monetary value. Industrial and Commercial Training, 38(3), 122-127.

Parris, D., \& Peachey, J. (2013). A systematic literature review of servant leadership theory in organizational contexts. Journal of Business Ethics, 113(3), 377-393.

Passmore, J., \& Fillery-Travis, A. (2011). A critical review of executive coaching research: A decade of progress and what's to come. Coaching: An International Journal of Theory, Research and Practice, 4(2), 70-88.

Passmore, J., \& Gibbes, C. (2007). The state of executive coaching research: What does the current literature tell us and what's next for coaching research? International Coaching Psychology Review, 2(2), 116-127.

Peltier, B. (2001). The psychology of executive coaching: Theory and application. New York, NY: Brunner-Routledge. 
Peterson, D. (1996). Executive coaching at work: The art of one-on-one change. Consulting Psychology Journal: Practice and Research, 48(2), 78-86.

Peterson, D., \& Millier, J. (2005). The alchemy of coaching: "You're good, Jennifer, but you could be really good!". Consulting Psychology Journal: Practice and Research, 57(1), 14-40.

Petty, R., \& Cacioppo, J. (1984). Motivational factors in consumer response to advertisements. In W. Beatty, R. Green, \& R. Arkin (Eds.), Human Motivation. New York: Allyn and Bacon.

Rekalde, I., Landeta, J., \& Albizu, E. (2015). Determining factors in the effectiveness of executive coaching as a management development tool. Management Decision, 53(8), 1677-1697.

Riggio, R., \& Lee, J. (2007). Emotional and interpersonal competencies and leader development. Human Resource Management Review, 17, 418-426.

Rocereto, J., Mosca, J., Forquer Gupta, S., \& Rosenberg, S. (2011). The influence of coaching on employee perceptions of supervisor effectiveness and organizational policies. Journal of Business \& Economics Research, 9(6), 15-23.

Rojon, C., McDowall, A., \& Saunders, M. (2011). On the experience of conducting a systematic review in industrial, work and organizational psychology: Yes it is worthwhile. Journal of Personnel Psychology, 10(3), 133-138.

Rousseau, D., Manning, J., \& Denyer, D. (2008). Evidence in management and organizational ccience: Assembling the field's full weight of scientific knowledge through syntheses. Academy of Management Annals, 2(1), 475-515.

Santos, A., \& Stuart, M. (2003). Employee perceptions and their influence on training effectiveness. Human Resource Management Journal, 13(1), 27-45.

Sauer, J. (1999). CEO succession planning in a petroleum exploration company: A case study. Consulting Psychology Journal: Practice and Research, 51(4), 266-272.

Scherer, R., Canty, A., Peterson, F., \& Cooper, R. (1995). Identification of managerial behavior dimensions in a federal health-care agency. PSychological Reports, 76(2), 675-679.

Schnell, E. (2005). A case study of executive coaching as a support mechanism during organizational growth and evolution. Consulting Psychology Journal: Practice and Research, 57(1), 41-56.

Scriffignano, R. (2011). Coaching within organisations: Examining the influence of goal orientation on leaders' professional development Coaching: An International Journal of Theory, Research and Practice, 4(1), 20-31.

Segers, J., Vloeberghs, D., Henderickx, E., \& Inceoglu, I. (2011). Structuring and understanding the coaching industry: The coaching cube. Academy of Management Learning \& Education, 10(2), 204-221.

Shadish, W., Cook, T., \& Campbell, D. (2002). Experimental and quasi-experimental designs for generalized causal inference. New York: Houghton Mifflin.

Smith Glasgow, M., Weinstock, B., Lachman, V., Dunphy Suplee, P., \& Dreher, H. (2009). The benefits of a leadership program and executive coaching for new nursing academic administrators: One college's experience. Journal of Professional Nursing, 25(4), 204210.

Smither, J., London, M., Flautt, R., Vargas, Y., \& Kucine, I. (2003). Can working with an executive coach improve multisource feedback ratings over time? A quasiexperimental field study. Personnel Psychology, 56, 23-44.

Sonesh, S., Coultas, C., Marlow, S., Lacerenza, C., Reyes, D., \& Salas, E. (2015). Coaching in the wild: Identifying factors that lead to success. Consulting Psychology Journal Practice and Research, 67(3), 189-217. 
Spence, G., Cavanagh, M., \& Grant, A. (2008). The integration of mindfulness training and health coaching: An exploratory study. Coaching: An International Journal of Theory, Research and Practice, 1(2), 145-163.

Stern, L., \& Stout-Rostron, S. (2013). What progress has been made in coaching research in relation to 16 ICRF focus areas from 2008 to 2012? Coaching: An International Journal of Theory, Research and Practice, 6(1), 72-96.

Stone, D. (2007). The status of theory and research in human resource management: Where have we been and where should we go from here? Human Resource Management Review, 17, 93-95.

Strayer, J., \& Rossett, A. (1994). Coaching sales performance: A case study. Performance Improvement Quarterly, 7(4), 39-53.

Styhre, A. (2008). Coaching as second-order observations: Learning from site managers in the construction industry. Leadership \& Organization Developement Journal, 29(3), 275-290.

Styhre, A., \& Josephson, P. (2007). Coaching the site manager: Effects on learning and managerial practice. Construction Management and Economics, 25, 1295-1304.

Sue-Chan, C., \& Latham, G. (2004). The relative effectiveness of external, peer, and selfcoaches. Applied Psychology: An International Review, 53(2), 260-278.

Swart, J., \& Kinnie, N. (2010). Organisational learning, knowledge assets and HR practices in professional service firms. Human Resource Management Journal, 20(1), 64-79.

Taie, E. (2011). Coaching as an approach to enhance performance. The Journal for Quality and Participation, 34(1), 34-38.

Teague, P., \& Roche, W. (2011). Line managers and hte management of workplace conflict: Evidence from Ireland. Human Resource Management Journal, 21(1), 1-17.

Thach, E. (2002). The impact of executive coaching and 360 feedback on leadership effectivness. Leadership \& Organization Developement Journal, 23(4), 205-214.

Theeboom, T., Beersma, B., \& van Vianen, A. (2014). Does coaching work? A meta-analysis on the effects of coaching on individual level outcomes in an organizational context. Journal of Positive Psychology, 9(1), 1-18.

Thorpe, R., Holt, R., Macpherson, A., \& Pittaway, L. (2005). Using knowledge within small and medium-sized firms: a systematic review of the evidence. International Journal of Management Reviews, 7(4), 257-281.

Ting, S., \& Hart, E. (2004). Formal coaching. In C. McCauley \& E. Van Velsor (Eds.), The Center for Creative Leadership Handbook of Leadership Development (pp. 116-150). San Francisco: John Wiley \& Sons.

Tobias, L. (1996). Coaching executives. Consulting Psychology Journal: Practice and Research, 48(2), 87-95.

Tranfield, D., Denyer, D., \& Smart, P. (2003). Towards a methodology for developing evidence-informed management knowledge by means of systematic review. British Journal of Management, 14, 207-222.

van Oorsouw, W., Embregts, P., \& Bosman, A. (2013). Quantitative and qualitative processes of change during staff-coaching sessions: An exploratory study. Research in Developmental Disabilities, 34(5), 1456-1467.

Van Velsor, E., \& Leslie, J. (1995). Why executives derail: Perspectives across time and cultures. Academy of Management Executive, 9(4), 62-72.

VanFleet, R. (1999). Diversifying psychology practice to industry: Getting started. The Pennsy/vania Psychologist Quarterly(May), 15 \& 24.

Wales, S. (2003). Why coaching? Journal of Change Management, 3(3), 275-282.

Wasylyshyn, K. (2003). Executive coaching: An outcome study. Consulting Psychology Journal: Practice and Research, 55(2), 94-106. 
Wasylyshyn, K., Gronsky, B., \& Hass, J. (2006). Tigers, Stripes, and behavior change: Survey results of a commissioned coaching program. Consulting Psychology Journal: Practice and Research, 58(2), 65-81.

Webster, \& Watson. (2002).

Webster, J., \& Watson, R. (2002). Analyzing the past to prepare for the future: Writing a literature review. MIS Quarterly, 26(2), xiii-xxiii.

Winum, P. (2005). Effectiveness of a high-potential African American executive: The anatomy of a coaching engagement. Consulting Psychology Journal: Practice and Research, 57(1), 71-89.

Witherspoon, R., \& White, R. (1996). Executive coaching: A continuum of roles. Consulting Psychology Journal: Practice and Research, 48(2), 124-133.

Wrench, J., McCroskey, J., Berletch, N., Powley, C., \& Wehr, A. (2008). Organizational coaching as instructional communication. Human Communication, 1193, 273-286. 